\author{
ТЕОРЕТИЧНИЙ ПІДХІД ДО ФОРМУВАННЯ КОНКУРЕНТОЗДАТНОСТІ \\ ЯК ФАКТОРУ УСПІШНОСТІ ПЕРВИННОЇ ВИРОБНИЧОЇ АДАПТАЦІЇ \\ МОЛОДИХ ФАХІВЦІВ ЗА УМОВ СУЧАСНОГО РИНКУ ПРАЦІ
}

\title{
THE THEORETICAL APPROACH TO FORMATION THE COMPETITIVENESS AS A FACTOR OF THE SUCCESS OF PRIMARY PRODUCTION ADAPTATION OF YOUNG SPECIALISTS IN THE CONDITIONS OF CURRENT LABOR MARKET
}

Стаття присвячена вивченню підходу до формування конкурентоздатності молодих фрахівців у прочесі їхнього навчання в закладах вищої освіти як детермінанти успішності первинної виробничої адаптації молодих фрахівців за умов сучасного ринку праці. Зокрема, розкрито сутність таких понять, як: «первинна виробнича адаптація молодого фрахівця», «дуальна модель професійної підготовки майбутнього фрахівця»; уточнено поняття «конкурентоздатність молодого фрахівця».

Первинна виробнича адаптація молодого фахівця тлумачиться як активний процес пристосування новачка до профресійної діяльності та виробничого колективу, внаслідок якого досягається оптимальна взаємодія особистості та виробничого середовища, есрективне «включення» молодого фрахівия у професійну діяльність і в систему виробничих і міжособистісних відносин у колективі. Позитивний результат первинної виробничої адаптації досягається за умови ідентисрікації молодого фрахівия з виробничим середовищем

Констатовано, що сформована конкурентоздатність молодого фрахівця є фрактором успішності його первинної виробничої адаптації до сучасного виробничого середовища. Конкурентоздатність молодого фрахівця розглядається як сукупність переваг, які людина отримала у процесі навчання в закладі вищої освіти, до яких належать: володіння досконалою системою спеціальних знань, умінь і навичок, розвиненість професійно значущих особистісних якостей, висока кваліфікація, відповідність вимогам сучасного ринку праці, наявність яких робить молодого фрахівця конкурентним для роботодавиів і здатним до вдалої та швидкої первинної виробничої адаптації до виробничого середовища.

З'ясовано, що сорормувати конкурентоздатність молодих фрахівців у процесі їхнього навчання в закладах вищої освіти можливо, якщо процес професійного навчання буде скоординований на вимоги роботодавців щодо якості підготовки фрахівців. Власне, досягнення наступності у професійній підготовці майбутніх фрахівців є тією системою підготовки, що спрямована на підготовку майбутніх фрахівців відповідно до вимог, висунутих роботодавцями.

Встановлено, що імплантація в систему профресійної освіти дуальної моделі професійної підготовки майбутнього фрахівця, під якою розуміється орорма організації практико-зорієнтованого навчання, заснована на принципах соціального партнерства, котра передбачає поєднання теоретич- ного та практичного навчання із частковою зайнятістю майбутнього фрахівия на підприємстві роботодавця, вимагає чітко скоординованої взаємодії освітньої та виробничої сорер, спрямованої на підготовку фрахівия певного профрілю відповідно до висунутих роботодавцем актуальних вимог сучасного ринку та передбачає встановлення ключової ролі та відповідальності роботодавця за якість просресійної підготовки фрахівия, дозволить досягти наступності у профре сійній підготовці майбутнього фрахівця, що посприяє формуванню конкурентоздатності молодого фрахівця в ході його навчання в закладі вищої освіти як фрактору успішності його первинної виробничої адаптації до виробничого середовища за умов сучасного ринку праці.

Ключові слова: молодий фрахівець, майбутній фрахівець, первинна виробнича адаптація, конкурентоздатність молодого фрахівця, дуальна модель професійної підготовки майбутнього фрахівця, професійна освіта, заклад вищої освіти.

The article is devoted to establishing an approach to formation the competitiveness of young specialists in the process of their education at institute of higher education, as determinants of the success of primary production adaptation of young specialists in the conditions of current labor market. In particular, the essence of such concepts as: "primary production adaptation of a young specialist", "dual model of vocational preparation of future specialist" have been revealed; the concept "competitiveness of a young specialist" has been clarified.

The primary production adaptation of a young specialist is interpreted as active process of adaptation of the beginner to professional activity and production team, as a result of which the optimal interaction of the individual and the production environment, effective "inclusion" of a young specialist in professional activity and in the system of production and interpersonal relations in the team are achieved. The positive result of primary production adaptation is achieved if a young specialist is identified with the production environment.

There has been stated, that the formed competitiveness of a young specialist is a factor in the success of his primery production adaptation to the current production environment.

The competitiveness of a young specialist is seen as a set of benefits that a person received in the process of studying at a institution of higher education, which include: possession of a perfect system of special knowledges, abilities and skills, maturity of professionally significant personal qualities, high qualification, compliance 
with the requirements of the current labor market, the presence of which makes a young specialist competitive for employers and capable of successful and rapid primery production adaptation to the production environment.

There has been found, that to form the competitiveness of young specialists in the process of their education at institute of higher education is possible, if the vocational training process will be coordinated to the requirements of employers regarding the quality of preparation of specialists. Namely the achievement of continuity in the vocational preparation of future specialists is the system of preparation that is aimed at vocational preparation of future specialists in accordance with the requirements of employers.

There has been found, that the implantation into the system of vocational education of a dual model of vocational preparation of the future specialist, which is understood as a form of organization of practice-oriented training, which is based on the principles of social partnership, which provides a combination of theoretical and practical training with part-time employment of the future specialist at the employer, requires a well-coordinated interaction of educational and production areas, aimed at preparation specialist of a certain profile in accordance with the actual requirements of the current labor market put forward by the employer and provides for the establishment of a key role and responsibility of the employer for the quality of vocational preparation, to allow the advancement of continuity in the vocational preparation of a future specialist, will allow achieving continuity in the vocational preparation of future specialists, which will contribute to the formation of the competitiveness of a young specialist during his training at the institute of higher education, as a factor in the success of his primary production adaptation to the production environment in conditions of current labor market.

Key words: young specialist, future specialist, primary production adaptation, competitiveness of a young specialist, dual model of vocationa preparation of the future specialist, vocational education, institute of higher education.
Постановка проблеми в загальному вигляді. У грудні 2005 р. Європейський Союз, а в лютому 2006 р. Сполучені Штати Америки офріційно надали Україні статус країни з ринковою економікою.

Перехід України до ринкової економіки викликав корінну трансформацію всієї сукупності виробничих відносин, які містять у собі трудові відносини. Ринок праці $\epsilon$ найбільш складним елементом ринкової економіки, тому що тут не тільки переплітаються інтереси фрахівців і роботодавця у процесі визначення ціни праці й умов фрункціонування, а й відбиваються практично всі соціально-економічні явища в суспільстві.

Сучасна ринкова економіка диктує жорсткі умови існування ринку праці, що вплинуло на появу нових вимог до фрахівців, зокрема молодих. Затребуваність працівника на сучасному ринку праці визначається сорормованістю в нього якостей фрахівця, які мають особливий попит на ринку праці, а саме: творчого потенціалу, гнучкості, здатності розв'язувати проблеми, аналізувати ситуації, вести вартісний аналіз, управляти ресурсами; швидкого освоєння різноманітних інновацій у тій ссрері просресійної діяльності, в якій особа працює, наявності громадянської відповідальності за прийняті рішення та наслідки своєї професійної діяльності. За умов ринкової економіки та розвитку науково-технічного прогресу окреслені якості фахівця постійно розширюються.

У ситуації, що склалася на ринку праці України, молодому фрахівцю особливо важко адаптуватися до нового для нього сучасного виробничого середовища, тому доцільним $є$ питання забезпечення успішності первинної виробничої адаптації молодого фрахівця, від вдалого перебігу якої багато в чому залежить працездатність фрахівця та робота підприємства (організації, установи, закладу тощо) взагалі.
Вивчення сучасного наукового фонду довело: переважна більшість учених і практиків (А.В. Бєлякова, В.В. Борисов, В.М. Данюк, І.С. Денисенко, І.Р. Ільмукова, О.В. Камкова, А.М. Колот, Л.І. Мороз, В.А. Савченко, Л.У. Стаут, О.С. Юрков та ін.) вважають, що у забезпеченні успішного перебігу первинної виробничої адаптації молодого фрахівця до сучасного виробничого середовища важливу роль відіграє організація управління роботодавцями цим процесом. Л.У. Стаут розроблено та впроваджено програми адаптації молодих фрахівців. І.С. Денисенко, базуючись на професійному досвіді, наголошує на важливості розроблення гнучких індивідуальних програм адаптації молодих фрахівців, які повинні створюватися лише спільно «Human Resources»-відділом і керівниками молодих працівників тощо. Проте статистика свідчить, що, незважаючи на організацію заходів щодо управління процесом адаптації молодих фрахівців із боку роботодавців, велика частка новачків не може пристосуватися до сучасного виробничого середовища через невідповідність жорстким і мінливим вимогам сучасного ринку праці, а тому звільняється.

Адаптуватися до виробничого середовища за умов сучасного ринку праці випускникам закладів вищої освіти допоможе розвинена конкурентоздатність молодих фрахівців (С.Я. Батишев, В.О. Бикова, Н.Т. Більдер, В.І. Бондар, Л.М. Мітіна, С.М. Савченко, І.П. Саратцева, О.О. Сушенцева, Є.В. Тараканова, Ф.Р. Туктарова, О. Чуба, Ж.А. Шуткіна та ін.). Отже, постає питання необхідності формування конкурентоздатності молодих фахівців у ході їхнього навчання в закладах вищої освіти, ссрормованість якої посприяє їхній адаптації до виробничого середовища за умов сучасного ринку праці.

Аналіз останніх досліджень і публікацій. За результатами аналізу науково-педагогічної літе- 
ратури зазначимо, що фрормування конкурентоздатності молодого фахівця під час його навчання в закладі вищої освіти в Україні та за ії̈ межами вже ставали предметом наукових розвідок учених. Так, способи розвитку конкурентоздатності у процесі саморозвитку досліджував В.І. Андрєєв; формування економічної культури як необхідного елементу забезпечення конкурентоздатності випускника закладу вищої освіти розглядала Т.Ю. Андріяко; В.О. Бикова обґрунтувала умови диверсиорікації освіти, що мають забезпечити ефективність управління процесом фрормування конкурентоздатних фрахівців; фрормування системи стійких особистісних якостей 3 метою розвитку конкурентоздатності особистості описувала Л.М. Мітіна; психолого-педагогічні умови розвитку конкурентоздатності молодих фрахівців висвітлювала С.А. Хазова. Водночас ще залишається невирішеним питання визначення підходу до фрормування конкурентоздатності молодих фрахівців у процесі їхнього навчання в закладах вищої освіти, розвиненість якої посприяє успішності їх первинної виробничої адаптації до виробничого середовища за умов сучасного ринку праці.

Мета статті полягає у встановленні на підставі вивчення наукової літератури способу фрормування конкурентоздатності як фрактору забезпечення успішності первинної виробничої адаптації молодих фрахівців за умов сучасного ринку праці.

Виклад основного матеріалу. Термін «адаптація» походить від латинського слова «adaptatio»пристосування.

Аналіз тлумачень поняття «адаптація», наданих у біології, фрізіології та медицині, довів, що взагалі під адаптацією розуміється процес і результат внутрішніх змін, зовнішнього активного пристосування та самозмін індивіда до нових умов буття [21, с. 17]. Але адаптація людини - це не стільки пристосування до фрізичних, біологічних умов, скільки пристосування особи до умов соціального середовища. Процес встановлення певних взаємин між людиною та соціальним середовищем у науковій літературі отримав назву «соціальна адаптація».

Соціальна адаптація - це процес пристосування особистості до наявних суспільних відносин, норм, зразків, цінностей, традицій суспільства, в якому живе та діє людина. Сутність соціальної адаптації як специфрічного соціального явища полягає в тому, що її підґрунтям є взаємодія між суспільним суб'єктом і соціальним об'єктом - умовами його суспільного буття. Суб'єктом соціальної адаптації виступає людина, особистість як індивідуальне буття соціальних відносин, об'єктом адаптації - соціальні умови, які містять матеріальні та соціальні компоненти [3].

У процесі життєдіяльності людина адаптується до багатьох сорер соціального середовища, як-от: сім'я, заклад освіти, нове місце мешкання, підприємство тощо. Відповідно до цього науковцями виокремлено різновиди соціальної адаптації, а саме: навчальну, виробничу та соціально-психологічну адаптацію [2].

Згідно 3 темою нашого дослідження розглянемо такий різновид соціальної адаптації, як виробнича, потреба в якій виникає щоразу, коли працівнику необхідно «включитися» в нове для нього виробниче середовище.

У свою чергу, виробниче середовище - це середовище, в якому людина здійснює свою професійну діяльність [13].

Теоретичні аспекти виробничої адаптації досліджувалися такими ученими, як: І.О. Баклицький, Н.А. Банько, Т.Н. Вершиніна, В.Г. Воронкова, Є.Ю. Жарова, А.Я. Кібанов, А.М. Колот, С.Я. Концовська, Є.В. Купріянчук, Л.І. Мороз, В.С. Савєльєва та ін.

Вивчення напрацювань окреслених авторів довело, що взагалі в науковій літературі під терміном «виробнича адаптація» розуміється активний процес пристосування новачка до умов професійної діяльності в новому для нього виробничому середовищі. Результатом процесу виробничої адаптації має виступити ідентифрікація, тобто «злиття» нового працівника з виробничим середовищем, асиміляція його 3 ним.

Учені Н.А. Банько, Т.Н. Вєршиніна, Є.Ю. Жарова, А.Я. Кібанов, Є.В. Купріянчук відзначили, що за наявністю в людини досвіду працевлаштування виробнича адаптація розподіляється на первинну та вторинну. Первинна виробнича адаптація відбувається під час «входження» молодого фрахівця у виробниче середовище (зазвичай ідеться про осіб, які не мають досвіду професійної діяльності, тобто про випускників закладів вищої або професійно-технічної освіти); вторинна виробнича адаптація - за умов зміни робітником робочого місця як усередині підприємства, так і поза його межами (йдеться про осіб, котрі мають досвід професійної діяльності) [6].

Перш ніж розпочати вивчення такого феномену, як первинна виробнича адаптація молодого фрахівця, визначимося з поняттям «молодий фрахівець», яке має трактування як із погляду законодавства, так і з позиції обивателя.

У юриспруденції під терміном «молодий фрахівець» розуміється громадянин України віком до 35 років, випускник закладу вищої або профресійно-технічної освіти незалежно від фрорми навчання, котрий отримав диплом встановленого державою зразка, працевлаштувався вперше протягом п'яти років після його отримання самостійно або за направленням закладу освіти чи територіального центрального органу виконавчої влади, що реалізує державну політику у сорері зайнятості населення та трудової міграції, та продовжує пра- 
цювати протягом трьох років за кваліфрікацією, яку він набув під час навчання, в т. ч. незалежно від місця першого працевлаштування [20]. Отже, у юридичному аспекті цим терміном визначаються норми, які встановлюють правове становище особи, котра володіє статусом молодого фахівця.

В іншому разі розуміння терміна «молодий фрахівець» доволі обмежене - це працівник, який нещодавно закінчив навчання в закладі вищої або профресійно-технічної освіти та якому бракує практичного досвіду щодо здійснення професійної діяльності певного напряму. За умов такого трактування правовий зміст дефрініції «молодий фрахівець» не враховується. Отже, як буденне поняття «молодий фрахівець» визначає особу, що $є$ випускником закладу вищої або профресійно-технічної освіти та має малий практичний досвід із виконання профресійної діяльності певної галузі.

У межах нашого дослідження під поняттям «молодий фрахівець» ми розуміємо особливу категорію трудових ресурсів, яка складається з випускників закладу вищої освіти будь-якого напряму професійної підготовки незалежно від фрорми навчання, котрі отримали диплом встановленого державою зразка. Ця категорія працівників перебуває на початковому рівні професійного становлення, володіє професійними знаннями, уміннями та навичками, у них розвинені професійно значущі особистісні якості, проте їм не вистачає профресійного досвіду зі здійснення професійної діяльності конкретної профресійної галузі.

Ретроспективний аналіз наукового фронду довів, що в колишньому СРСР глобальне вивчення проблеми первинної виробничої адаптації молодого фрахівця було розпочато в середині 60-х рр. минулого століття. Вивченням цього питання займалися такі вчені, як: С.Д. Артьомов, В.Г. Асєєв, М.П. Будякіна, Т.Н. Вєршиніна, Ф.Д. Кутц, Н.П. Лукашевич, В.А. Самойлова, Є.В. Таранов, В.Н. Шубкін та ін.

На теренах пострадянського простору висвітленню процесу первинної виробничої адаптації молодого фрахівця до виробничого середовища присвятила свої наукові праці низка вчених, а саме: І.О. Баклицький, А.В. Бєлякова, В.В. Борисов, В.М. Данюк, І.Р. Ільмукова, О.В. Камкова, О.С. Юрков та ін.

Огляд наукової літератури часового проміжку із середини 60-х рp. XX - початку XXI ст. дозволив зробити висновок, що науковці як минулих часів, так і сьогодення одностайні в підході до визначення поняття «первинна виробнича адаптація молодого фрахівця».

На підставі узагальнення наданих окресленими вище вченими трактувань з'ясовано, що в науковій літературі під первинною виробничою адаптацією молодого фрахівця розуміється активний процес пристосування новачка до професійної діяльності та виробничого колективу, внаслідок якого досяга- ється оптимальна взаємодія особистості та виробничого середовища, ефективне «включення» молодого фрахівця у професійну діяльність і в систему виробничих і міжособистісних відносин у колективі. Позитивний результат первинної виробничої адаптації досягається за умови ідентифікації молодого фахівця з виробничим середовищем.

Такі науковці, як С.Я. Батишев, В.О. Бикова, Н.Т. Більдер, В.І. Бондар, Л.М. Мітіна, С.М. Савченко, І.П. Саратцева, О.О. Сушенцева, Є.В. Тараканова, Ф.Р. Туктарова, О. Чуба, Ж.А. Шуткіна та ін., дослідження яких пов'язані з вивченням сутності поняття «конкурентоздатність молодого фрахівця», вважають, що розвинена конкурентоздатність молодих фрахівців дозволяє їм значно легше адаптуватися до жорстких вимог сучасного виробничого середовища, досягаючи більш високого рівня професійного й особистісного розвитку.

Українська дослідниця В.О. Бикова [5] під конкурентоздатністю молодого фрахівця розуміє складну, багаторівневу інтегральну властивість особистості, яка дозволяє їй відповідно до її індивідуальних властивостей, потреб, прагнень брати участь й отримувати переваги у конкурентних відносинах в обраній нею сорері професійної діяльності. Як відзначила авторка, конкурентоздатність молодого фрахівця $є$ не лише результатом його навчання у профресійному закладі освіти будьякого рівня, а і його особистістю, яка має певні якості, може досягти високих результатів у своїй професійній діяльності та зробити внесок у досягнення організації. Характеризуючи конкурентоздатного молодого фахівця, В.О. Бикова наголосила, що це зорієнтований на успіх профресіонал із яскраво вираженою потребою в досягненні успіху, збагаченні знань і їх застосуванні у професійній діяльності, оновленні професійного досвіду, творчому самовираженні, відрізняється він самостійністю прийняття рішень і дій, розвинутим емоційним інтелектом, притаманною для нього є здатність до адаптації у професійному конкурентному середовищі, адекватної оцінки дійсності, рефлексії власної діяльності. Конкурентоздатні молоді фрахівці повинні бути мобільними, прагнути до безперервного підвищення професійної майстерності та володіти високою адаптаційною і професійною мобільністю; бути спроможними до створення та використання високих технологій; володіти сформованими міцними моральними засадами, розвиненою цивілізаційною культурою, відповідальністю та толерантністю; готовими до нового типу громадських відносин, які перебувають у постійній динаміці та виявляються в переходах від однієї соціально-професійної ролі до іншої. Також учена зауважила, що конкурентоздатність молодого фахівця - це не лише відповідність або невідповідність (конкурентна перевага) трудового потенціалу фрахівця висунутим вимогам, але і ступінь 
відповідності попиту роботодавця, критеріям і мінливим вимогам ринку праці стосовно професійноосвітнього рівня, кваліфікації, віку, статі, ділових та особистих якостей порівняно 3 відповідними характеристиками інших працівників, котрі теж пропонують себе на ринку праці [5].

У контексті вищезазначеного під конкурентоздатністю молодого фрахівця ми розуміємо сукупність переваг, які людина отримала у процесі навчання в закладі вищої освіти, до яких належать: володіння досконалою системою спеціальних знань, умінь і навичок, розвиненість професійно значущих особистісних якостей, висока кваліфікація, відповідність вимогам сучасного ринку праці, наявність яких робить молодого фахівця конкурентним для роботодавців і здатним до вдалої та швидкої первинної виробничої адаптації до виробничого середовища.

Отже, сорормована конкурентоздатність молодого фрахівця виступає як фактор успішності його первинної виробничої адаптації до сучасного виробничого середовища. Виходячи 3 цього, дослідимо шлях фрормування конкурентоздатності молодого фрахівця у процесі його навчання в закладі вищої освіти.

Л.А. Семенова зазначає, що сорормувати конкурентоздатних молодих фрахівців під час їхнього навчання в закладах вищої освіти можливо, якщо процес професійного навчання буде скоординований на вимоги роботодавців щодо якості підготовки фахівців. Як наголошує вчена, саме забезпечення наступності у профресійній освіті дозволить зорієнтувати процес професійного навчання на вимоги сучасного роботодавця щодо якості підготовки фрахівців, що посприяє розвитку конкурентоздатних особистостей [22]

Традиційно поняття «наступність» розглядається як зв'язок між різними щаблинами розвитку, який полягає у збереженні окремих елементів або характеристик цілого у процесі переходу до нового стану [24, с. 408]. Це тлумачення терміна «наступність» $€$ підґрунтям для розуміння сутності наступності в педагогіці, зокрема у професійній педагогіці.

У професійній педагогіці наступність трактується як ієрархічна система впливів, у якій процес формування особистісних і профресійних якостей у майбутнього фрахівця, потрібні для високої культури праці, наукової організації праці та виробництва, представлений двома рівнями: «нижні» рівні цілей навчання конкретизують цілі більш «високого» рівня навчання. Забезпечення узгодженості між рівнями цілей навчання є задачею системи профресійної освіти [23].

Вивчення науково-педагогічної літератури (О.П. Андрєєва, Л.А. Горшунова, Н.П. Харьковський та ін.) довело, що в педагогіці існує два напрями реалізації наступності, а саме: «по горизонталі» - в межах одного й того самого навчального закладу (наступність між елементами загальної системи освітнього процесу) та «по вертикалі» - в межах різних навчальних закладів (наступність між роботою дитячого садка та школи; наступність між школою і закладом вищої освіти; наступність між закладом профресійно-технічної освіти та закладом вищої освіти та ін.) [10]. Н.П. Харьковським відзначено, що зміст «горизонтальної» наступності містить фрормування цілісного знання, заснованого на послідовному вивченні навчального матеріалу, використанні інноваційних технологій і вимог до результатів, які відповідають змісту навчання. До змісту «вертикальної» наступності, на думку автора, належить підготовка до профресійної діяльності, послідовність у вивченні навчальних дисциплін, фрорм, методів і засобів професійного навчання [25].

На підставі докладного вивчення досліджень І.Р. Накової [16], Н.П. Харьковського [25] з'ясовано, що мета впровадження вертикального вектору наступності в освіту полягає в забезпеченні наступності в підготовці, яка відбивається на рівні готовності особи до існування в соціальній сфері більш високого рівня.

Важливого значення в контексті зазначеного вище набуло твердження С.Я. Батишева [4], котрий вважає, що саме наступність у професійній підготовці майбутнього фахівця - це та система підготовки, яка зорієнтована на вимоги роботодавців щодо якості підготовки фрахівців, на фрормування конкурентоздатних молодих фрахівців у процесі їхнього навчання у профресійних закладах освіти будь-якого рівня.

Отже, власне пенетрація «вертикальної» наступності в систему професійної освіти послугує забезпеченню наступності у професійній підготовці майбутнього фрахівця, що дозволить врахувати вимоги, які висуваються роботодавцями до змісту профресійної освіти у процесі підготовки майбутніх фахівців, що посприяє формуванню конкурентоздатності особистостей, розвиненість якої вплине на успішний перебіг їх первинної виробничої адаптації до сучасного виробничого середовища.

3'ясуємо, яким чином можна досягти наступності у профресійній підготовці майбутнього фрахівця.

Змістове наповнення поняття «професійна підготовка» позиційовано в напрацюваннях А.О. Абдуліної, Н.П. Волкової, І.В. Морозової, Л.П. Поліщук, М.Г. Савельєвої, В.А. Сластьоніна, В.Ф. Чебукіної та ін. Узагальнення наданих окресленими авторами визначень терміна «професійна підготовка» дало змогу встановити, що в науково-педагогічній літературі під терміном «професійна підготовка майбутнього фрахівця» розуміється складний, багатоаспектний процес, який вимагає реалізації комплексного підходу до врахування вимог сучасного суспільства та спрямований на формування 
й удосконалення знань, умінь і навичок, необхідних майбутньому фахівцю для розв'язання певних професійних задач, розвиток професійно значущих якостей особистості, набуття професійного досвіду та норм поведінки, що забезпечить йому можливість успішно виконувати професійну діяльність за певною професійною галуззю.

Найважливішою складовою частиною професійної підготовки майбутнього фрахівця, істотною передумовою успішного виконання ним профресійної діяльності є практична підготовка, завдання, зміст, організаційні форми, методичне забезпечення якої повинні сприяти оволодінню особою, котра навчається, основами професійних умінь і навичок, а також допомогти їй у фрормуванні професійно значущих якостей особистості. Практика того, хто навчається, є важливою ланкою системи його підготовки у закладі вищої освіти (А.В. Літвін, Н.М. Мірончук, І.В. Морозова, І.Я. Нєволіна, Л.П. Поліщук, В.Ф. Чебукіна та ін.).

У довідковій літературі термін «практична підготовка» тлумачиться як діяльність, зорієнтована на отримання майбутніми фахівцями практичних умінь і навичок у процесі проходження ними виробничої (профресійної) практики [7, с. 247]. Метою організації та проведення практики $є$ оволодіння особами, котрі навчаються, сучасними методами, формами організації та знаряддями праці в галузі їхньої майбутньої професії, фрормування в них на базі одержаних у закладі вищої освіти професійних знань умінь і навичок для самостійного прийняття рішень під час конкретної роботи за реальних ринкових і виробничих умов, виховання потреби систематично поновлювати свої знання та творчо їх застосовувати у практичній діяльності. Практика здобувачів вищої освіти передбачає безперервність і послідовність її проведення за умови попереднього отримання потрібного обсягу практичних умінь і навичок [17].

Отже, базисним компонентом процесу професійної підготовки майбутнього фрахівця, який дозволяє створити умови для об'єднання на підставі взаємопроникнення навчання та профресійної діяльності тих, хто навчається в закладі вищої освіти, є практико-зорієнтоване навчання в системі профресійної освіти, під яким розуміється процес освоєння особами, котрі навчаються, освітньої програми з метою фрормування в них навичок практичної діяльності за рахунок виконання ними реальних практичних завдань. Основу практикоорієнтованого навчання становить оптимальне поєднання фрундаментальної освіти та прикладної підготовки [18].

Науковці Л.Г. Ананченко, Є.Н. Лєнівко [1], Л.А. Янковська, Р.М. Захарчін [26] одноголосні в тому, що випускникам закладів вищої освіти для успішного кар'єрного росту, реалізації амбітних планів і прагнень бути сучасними, тобто конку- рентоздатними у глобалізованому середовищі, необхідно бути обізнаними з тонкощами працевлаштування та швидкої адаптації, потрібно володіти на високому рівні знаннями, уміннями та навичками з фаху, певним досвідом профресійної діяльності, в них мають бути сфрормовані професійні якості особистості, чому посприяє вдосконалення практико-зорієнтовного освітнього процесу з підготовки майбутніх фрахівців через розвинення взаємозв'язків між професійними закладами освіти будь-якого рівня й організаціями-замовниками робочих кадрів на підставі соціального партнерства у професійній освіті.

Вивчення досліджень (Є.Ю. Єсєніна [11], Т.А. Іваничева [12] та ін.) та нормативних документів України [19] довело, що існує практика ототожнення практико-зорієнтовного навчання, заснованого на засадах соціального партнерства у професійній освіті, з дуальною системою професійної освіти.

У педагогіці поняття «дуальна система» вперше було використано у ФРН у середині 60-х рр. XX ст. для позначення нової форми організації профресійної освіти. Зародившись у Німеччині, дуальна система професійної освіти надалі поширилася у світовій практиці профресійної освіти.

Науковці Німеччини під дуальною системою просресійної освіти розуміють такий освітній процес, що поєднує практичне навчання з частковою зайнятістю на виробництві та навчання у традиційному закладі освіти [28]. Тобто дуальна система профресійної освіти - це два навчально-виробничі середовища, як от: роботодавець і профресійна школа, які діють разом із метою досягнення спільної мети - професійної підготовки майбутніх фрахівців [27].

Т.А. Іваничева наголошує, що механізмом реалізації дуальної системи професійної освіти є соціальне партнерство [12].

Розкриттю сутності поняття «соціальне партнерство у професійній освіті» присвятили свої дослідження такі науковці, як: І.А. Артемьєв, В.А. Галанов, Т.М. Глушанюк, Л.Ю. Кримчак, П.М. Кухарчук, Є.3. Муратшин, Л.К. Мухпамбетова, В.С. Чванов та ін. Вивчення досліджень зазначених учених довело, що науковці одностайні у трактуванні цього поняття. Так, під «соціальним партнерством у професійній освіті» вони розуміють особливий тип взаємодії професійних закладів освіти будь-якого рівня 3 потенційними роботодавцями, спрямований на максимальне узгодження та реалізацію інтересів учасників процесу підготовки фахівців за дуальною системою профресійної освіти [9]. Сутність цієї взаємодії полягає в тому, що, з одного боку, сфера освіти повинна здійснювати професійне навчання відповідно до вимог сучасного ринку праці, з іншого роботодавці повинні брати активну участь у виро- 
бленні стратегії освіти, контролюванні її якості [8]. Основна мета організації соціального партнерства полягає у сприянні процесу профресійної підготовки конкурентоздатних молодих фахівців у період їхнього навчання у професійному закладі освіти будь-якого рівня [15].

Ґрунтовне вивчення напрацювань Н.В. Літвінової та Є.І. Смолєр [14] довело, що використання соціального партнерства між двома суміжними соціальними сорерами посприяє встановленню наступності «по вертикалі» в освіті.

Тож під дуальною системою професійної освіти ми розуміємо практико-зорієнтовне навчання, побудоване на засадах соціального партнерства, засадничим принципом якого $€$ «вертикальна» наступність у професійній освіті, мета організації такого навчання полягає у створенні дуальної моделі професійної підготовки майбутнього фрахівця.

Концептуальність дефініції «дуальна модель профресійної підготовки майбутнього фрахівця» розглядалася такими авторами, як: Т.А. Іваничева, Ю.Н. Пєтров, Д.А. Растєгаєва, Р.В. Сєлюков, Є.В. Тєрєщєнкова, Ю.В. Щекіна та ін. Підсумовуючи представлені в науково-педагогічній літературі визначення цього поняття, під дуальною моделлю профресійної підготовки майбутнього фрахівця розуміємо таку форму організації практико-зорієнтованого навчання, яка заснована на принципах соціального партнерства, що передбачає поєднання теоретичного та практичного навчання із частковою зайнятістю майбутнього фрахівця на підприємстві (в організації, установі, закладі тощо) роботодавця, що вимагає чітко скоординованої взаємодії освітньої та виробничої сорер, спрямованої на підготовку фахівця певного профрілю відповідно до висунутих роботодавцем актуальних вимог сучасного ринку праці та передбачає встановлення ключової ролі та відповідальності роботодавця за якість профресійної підготовки фахівця.

Виходячи з вищеокресленого, вважаємо, що досягнення наступності у професійній підготовці майбутнього фрахівця ми вбачаємо в імплементації дуальної моделі професійної підготовки майбутнього фрахівця в систему професійної освіти, що спрямує процес професійної підготовки на вимоги роботодавців щодо якості підготовки фрахівців, а це дозволить сорормувати конкурентоздатність молодих фахівців, завдяки розвиненості якої вони зможуть вдало подолати процес первинної виробничої адаптації до умов нового для них сучасного виробничого середовища.

Висновки. Таким чином, встановлено, що сфрормувати конкурентоздатність молодого фахівця у процесі його навчання в закладі вищої освіти як фактору успішності його первинної адаптації до виробничого середовища за умов сучасного ринку праці дозволить упровадження в систему профе- сійної освіти дуальної моделі профресійної підготовки майбутнього фрахівця.

3 метою набуття досвіду з розробки та реалізації дуальної моделі професійної підготовки майбутнього фрахівця кафедра технологічної та професійної освіти Художньо-графрічного фракультету Державного закладу «Південноукраїнський національний педагогічний університет імені К.Д. Ушинського» залучилася до участі в міжнародному проєкті Erasmus + KA2 CBНЕ «Нові механізми управління на основі партнерства та стандартизації підготовки викладачів професійної освіти в Україні» (PAGOSTE) 609536 - EPP - 1 - 2019 DE - EPPKA2 - CBHE - SP.

Перспектива подальших досліджень полягає в розробці дуальної моделі профресійної підготовки майбутнього фрахівця й експериментальній перевірці дієвості її упровадження в систему професійної освіти 3 метою формування конкурентоздатності майбутніх фрахівців.

\section{БІБЛІОГРАФІЧНИЙ СПИСОК:}

1. Ананченко Л.Г., Ленивко Е.Н. Практическая подготовка студентов на предприятиях-работодателях и вовлечение их в процессы производства. Проблемы современного образования в техническом вузе : материалы V Междунар. науч.-метод. конфр., 26-27 окт. 2017 г. : тезы докл. Гомель : ГГТУ им. П.О. Сухого, 2017. С. 153-155.

2. Асеев В.Г. Теоретические аспекты проблемы адаптации. Адаптация учащихся и молодежи к трудовой и учебной деятельности : сборник статей I отв. ред. В.Г. Асеев. Иркутск : ИГПИ, 1986. С. 3-19.

3. Артемов С.Д. Проблемы социальной адаптации молодого рабочего на социалистическом промышленном предприятии : автореф. дисс. ... канд. фрилос. наук : 09.620. Свердловск, 1970. 19 с.

4. Батышев С.Я. Подготовка рабочих широкого профиля в условиях перехода к рыночной экономике. Москва : Ассоциация «Профрессионального образования», 1993. Ч. 2. 196 с.

5. Бикова В.О. Управління процесом формування конкурентоздатного фрахівця в умовах диверсифрікації освіти : автореср. дис. ... канд. пед. наук : 13.00.06. Луганськ, 2013. 20 с.

6. Вершинина Т.Н. Взаимосвязь текучести и производственной адаптации рабочих / отв. ред. 3.В. Куприянова. Новосибирск : Наука : Сиб. отд-ние, 1986. 164 c.

7. Вишнякова С.М. Профессиональное образование: Словарь: Ключевые понятия, термины, актуальная лексика. Москва : Новь, 1999. 535 с.

8. Галанов В.А. Социальное партнерство и ОдО. Университетское управление: практика и анализ. 2000. № 1. C. 31-32. URL: http://hdl.handle. net/10995/4280 (дата звернення: 07.07.2020).

9. Глушанок Т.М. Социальное партнерство как средство повышения качества профессионального образования. Современные проблемы науки и образования. 2008. № 6. C. 80-83. URL: https://scienceeducation.ru/ru/article/view?id=1144 (дата звернення: 12.06.2020). 
10. Горшунова Л.А. Преемственность управления подготовкой учителя в системе непрерывного образования: проблемы и перспективы / науч. ред. А.Н. Орлов. Москва ; Барнаул : АГУ, 2001. 208 с.

11. Есенина Е.Ю. Дуальное обучение: возможности, ограничения, условия и практика использования. Профрессиональное образование и рынок mpyда. 2015. № 8. C. 16-18. URL: https://cyberleninka. ru/article/n/dualnoe-obuchenie-vozmozhnostiogranicheniya-usloviya-i-praktika-ispolzovaniya/viewer (дата звернення: 15.03.2020).

12. Иванычева Т.А. Практико-ориентированная (дуальная) модель подготовки квалифицированных рабочих кадров и специалистов среднего звена : методическое пособие. Тюмень : ТОГИРРО, 2017. 52 с.

13. Лапін В.М. Безпека життєдіяльності людини : навчальний посібник. Львів : Львівський банківський коледж, 1998. 192 с.

14. Литвина Н.В., Смолер Е.И. Социальное партнерство - основа преемственности во взаимодействии учреждения дошкольного образования и начальной школы. Подготовка учителя начальных классов: проблемы и перспективы : материалы IV Междунар. научн.-практ. конфр.; Минск : БГПУ, 2017. URL: http://elib.bspu.by/handle/doc/40411 (дата звернення: 12.06.2020).

15. Мухамбетова Л.К., Дюсембаев А. Развитие социального партнерства в профессиональном образовании. URL: http://www.rusnauka.com/12 KPSN_2013/Pedagogica/2_135533.doc.htm (дата звернення: 12.06.2020).

16. Накова И.Р. Оптимизация преемственности при подготовке к обучению в условиях комплекса «детский сад-школа» : дис. ... канд. пед. наук : 13.00.01. Владикавказ, 2000. 210 с.

17. Положення про проведення практики студентів вищих навчальних закладів України : Наказ Міністерства освіти України № 93 від 08 квітня 1993 р. URL: https://zakon.rada.gov.ua/laws/show/z0035-93\#Text (дата звернення: 31.03.2020).

18. Полисадов С.С. Практико-ориентированное обучение в вузе. URL: https://portal.tpu.ru/f_dite/conf/2014/2/ c2_Polisadov.pdf (дата звернення: 30.08.2020).

19. Про впровадження елементів дуальної фрорми навчання у професійну підготовку кваліфрікованих робітників : Лист Департаменту профресійної освіти
MOH України № 3-545 від 14 липня 2017 р. URL: http://vpu-4.com.ua/images/Дуальна_фрорма_ навчання/Додаток_1_Положення_по_дуальн_сист. pdf (дата звернення: 17.06.2020).

20. Про забезпечення молодих фрахівців першим робочим місцем із звільненням роботодавця від сплати єдиного внеску на загальнообов'язкове державне соціальне страхування : Проект закону України № 2011а від 15 травня 2013 р. URL: http://spo.fpsu.org.ua/images/files/zakonoproekt_2011a. doc (дата звернення: 16.03.2020).

21. Реан А.А., Кудашев А.Р., Баранов А.А. Психологическая адаптация личности. Анализ. Теория. Практика. Санкт-Петербург : прайи-ЕВРО-ЗНАК, 2006. 479 c.

22. Семенова Л.А. Преемственность профессионального образования как понятие. Концепт. 2015. T. 13. C. 1436-1440. URL: http://e-koncept.ru/ 2015/85288.htm (дата звернення: 14.03.2020).

23. Тогаев Г.Ш. Преемственность процесса воспитания в профессиональной подготовке молодежи. Academy. № 6 (21). 2017. Т. 1. С. 78-80. URL: $\quad$ https://academicjournal.ru/images/PDF/2017/ Academy-6-21.pdf/Academy-6-21--1-.pdf (дата звернення: 11.03.2020).

24. Філософський енциклопедичний словник : енциклопедія / голов. ред. В.І. Шинкарук. Київ : Абрис, 2002. 742 C.

25. Харьковский Н.П. Преемственность подготовки специалистов-дизайнеров в контексте непрерывного образования : дис. ... канд. пед. наук : 13.00.08. Елец, 2005. 197 с.

26. Янковська Л.А., Захарчин Р.М. Професійнопрактична підготовка фрахівців у вищій школі та іiі інноваційний розвиток у фрорматі «держава вищі навчальні заклади - роботодавці». Науковий вісник НЛтУ України. 2012. Вип. 22.4. С. 367-373. URL: $\quad$ https://cyberleninka.ru/article/n/profesiynopraktichna-pidgotovka-fahivtsiv-u-vischiy-shkoli-tayiyi-innovatsiyniy-rozvitok-u-formati-derzhava-vischinavchalni-zakladi/viewer (дата звернення: 01.04.2020).

27. Schelten A. Einfuhrung in die Berufspedagogik, Stuttgart : Stainer, 1991. 289 p.

28. Schulz K. Das duale System der Beruflichen Bildung in Deutschland. Darstellung und Kritik. Munchen : Grin Verlag, 2007. 64 p. 